\title{
Phytogenic Additives and Glutamine Plus Glutamic Acid in Broiler Diets

\section{-Author(s)}

Pelícia VC'

Stradiotti $\mathrm{AC}^{\prime}$

Araujo PC de

Maruno MK

Carvalho FB del

Pezzato AC'

Sartori JR'

Universidade Estadual Paulista (UNESP), Faculdade de Medicina Veterinária e Zootecnia, Botucatu, SP, Brasil.

" Universidade Federal de Goiás (UFG), Escola de Veterinária, Goiânia, GO, Brasil.

\section{nMail Adress}

Corresponding author e-mail address Vanessa Cristina Pelícia

Faculdade de Medicina Veterinária e Zootecnia, UNESP, Campus de Botucatu. Distrito de Rubião Júnior, s/n, Caixa postal 560, CEP: 18618-000, Botucatu-SP. E-mail:vcpelicia@yahoo.com.br

\section{nKeywords}

Alternative additives, plant extracts, essential oils.

\section{ABSTRACT}

The objective of this study was to evaluate the effect of the dietary supplementation of phytogenic additives (PAs) and glutamine plus glutamic acid ( $\mathrm{Gln} / \mathrm{Glu}$ ), associated or not, in replacement of antibiotic growth promoters and anticoccidials (AGP/AC) on the performance and carcass yield of broilers. Five hundred male Cobb broilers were housed in an experimental house and randomly distributed into five treatments, with four replicates of 25 birds each. Treatments consisted of a control diet (CD); CD+AGP/AC; CD+Gln/Glu; CD+PAs; CD+Gln/ Glu+PAs. Diets were formulated only with plant feedstuffs, i.e., they did not contain any animal byproducts. Performance data were collected for the accumulated periods of 1-7, 1-21, and 1-42 days of age. Carcass yield and parts yield were determined at 42 days of age. Treatments did not influence performance during none of the evaluated periods. The greatest carcass yield $(p<0.05)$ was obtained in birds in the treatments $C D+G \ln / G l u$ and $C D+G \ln / G l u+P A s$ relative to $C D$, but not different from birds in the $A G P+A C$ and PAs treatments, which were not different from the $C D$ treatment. Birds fed the $C D+G \ln / G l u$ diet presented greater breast yield $(p<0.05)$ compared with those in the CD and AGP/AC treatments, but there was no difference in comparison with the other treatments. Under the conditions of the present experiment, the dietary supplementation with phytogenic additives and with glutamine plus glutamic acid does not affect the performance, but improves carcass yield and breast yield of broilers.

\section{INTRODUCTION}

The public is increasingly concerned with animal welfare and food safety and quality. Also, there is a growing public pressure at domestic and international level against the addition of low doses of antibiotics and chemotherapeutic drugs in animal feeds, with a consequent increasing demand for the so-called alternative animal products, particularly for alternative poultry products. Alternative chicken products are those derived from industrial broilers that were not fed antibiotic growth promoters, anticoccidials, or animal feedstuffs and that were reared at lower stocking density, i.e., at a maximum of 12 birds $/ \mathrm{m}^{2}$ (Demattê Filho $\&$ Mendes, 2001). Therefore, there is a need to search for alternative natural additives to replace antibiotics and chemotherapic drugs in broiler diets with beneficial effects on broiler intestinal flora, thereby protecting the birds against pathogens, controlling or preventing diseases, and improving the efficiency of nutrient utilization.

Several researchers (Bartel \& Batal, 2007; Murakami et al., 2007; Lora et al., 2006; Mcreynolds et al., 2009) observed the beneficial effects of glutamine and glutamic acid, as well as phytogenic additives (essential oils and plant extracts) on broiler immune response and 
intestinal microflora and structure, and consequently, on broiler performance, particularly in the presence of health challenges.

Glutamine (GIn) and glutamic acid (Glu) are important energy substrates for high turnover cells, such as those of the immune system and of the intestinal mucosa (Windmueller \& Spaeth, 1974; Newsholme et al., 1985; Newsholme, 2001; Piva et al., 2001; Newsholme et al., 2003a and b), in addition of being part of proteins and peptides. Glutamine is also used for the synthesis of other amino acids and nucleotides (Wu, 1998).

Bartel \& Batal (2007) observed higher antibody levels in broilers fed a Gln-supplemented diet compared to those not fed GIn. When supplementing 1\% GIn to broiler diets, Maiorka et al. (2000), Sakamoto et al. (2005), and Murakami et al. (2007) observed beneficial effects on the development of the intestinal mucosa in one-week-old broilers, with better nutrient digestion and absorption capacities, which may improve their performance.

Lora et al. (2006) studied the effect of the inclusion of different levels of a product containing a mixture of glutamine and glutamic acid (10\% each) on the performance of 1- to 42-d-old broilers reared on reused litter. Broilers fed the mixture at 0.5, 1.0, and 1.5\% presented higher weight gain relative to the control birds during the entire experimental period. The best production efficiency index was obtained with the $1.0 \%$ inclusion level.

Phytogenic additives (PAs) are products derived from plants and consist mostly of plant extracts (PEs) and essential oils (EOs). The reported therapeutic properties of these additives include antimicrobial activity (McReynolds et al., 2009), anticoccidial activity (Miguel et al., 2009), and better nutrient digestibility and broiler performance (García et al., 2007; Fascina et al., 2010 e 2012).

Considering the reported beneficial effects of these natural additives on the intestinal structure, nutrient digestibility, and immune system of broilers, it may be possible to use them to replace antibiotic growth promoters and chemotherapeutic drugs.

The objective of this study was to evaluate the effect of the dietary supplementation with phytogenic additives and glutamine plus glutamic acid, associated or not, as an alternative to the inclusion of antibiotic growth promoter and anticoccidials on the performance and carcass yield and parts yield of broilers.

\section{MATERIALS AND METHODS}

The study was carried out at the facilities of the Poultry Nutrition Laboratory, School of Veterinary Medicine and Animal Science, Universidade Estadual Paulista (UNESP), Botucatu campus. The trial was approved by the Committee of Ethics of Animal Experimentation (protocol n. 07/2009, CEEA).

Five hundred one-d-old male Cobb broilers were housed on a twice-reused litter at a density of 10 birds $/ \mathrm{m}^{2}$, as recommended for alternative broiler production (Demattê Filho \& Mendes, 2001). Chicks were vaccinated in the hatchery against Marek's disease, infectious bursal disease (IBD), and fowl pox. Birds received booster vaccine against IBD at eight and 14 days of age.

A completely randomized experimental design, of five treatments with four replicates of 25 birds each, was applied. Treatments consisted of a control diet with no antibiotic growth promoters or anticoccidials (CD); $C D+$ antibiotic growth promoter ${ }^{1}$ and anticoccidial ${ }^{2}$ (AGP/AC); CD+glutamine+glutamic $\operatorname{acid}^{3}(\mathrm{Gln} / \mathrm{Glu}) ; C D+$ phytogenic additive ${ }^{4}$ (PAs), and; $\mathrm{CD}+\mathrm{G} \ln / \mathrm{Glu}+\mathrm{PAs}$

Glutamine and glutamic acid were added to the diets at the expense of corn starch as they have similar energy values, while the other additives were added at the expense of inter material (kaolin), according to the recommendations of the manufacturer.

The rearing period was divided in four phases: pre-starter, starter, grower, and finisher. Feeds were formulated according to the nutritional requirement tables of Rostagno et al. (2005), as shown in Table 1.

Performance data were collected and analyzed for the accumulated periods of 1-7, 1-21, and 1-42 days of age. The following parameters were calculated: weight gain (difference between body weight at the end of each period and body weight at housing; feed

1 Surmax $^{\circledR} 10 \%$, Elanco (avilamycin): 10ppm inclusion level.

${ }^{2}$ Monenpac $^{\circledR}, \mathrm{M}$ Cassab (monensin): 100ppm inclusion level.

3 AminoGut ${ }^{\circledR}$, Ajinomoto (guaranteed minimal levels: $10 \%$ glutamine and $10 \%$ de glutamic acid): $1.0 \%$ inclusion days $1-21$ and 0.5 inclusion days 22-42.

${ }^{4}$ Imunostart $^{\circledR}$, M Cassab (composed of turmeric extract, citrus extract, and grape seed extract): inclusion of $700 \mathrm{~g} / \mathrm{ton}$ feed days 1-10; 500g/ton days 11-21; Enterocox ${ }^{\circledR}$, M Cassab (composed of eucalyptus oil, cinnamon essential oil, boldo leaves, fenugreek seeds): inclusion of $300 \mathrm{~g} /$ ton days 1-10, $1000 \mathrm{~g} /$ ton days $11-35$, and $500 \mathrm{~g} /$ ton days $36-42$. 
Table 1 - Composition of the control diets according to rearing phase.

\begin{tabular}{|c|c|c|c|c|}
\hline $\begin{array}{l}\text { Ingredients } \\
(\%)\end{array}$ & $\begin{array}{c}\text { Pre-starter } \\
1-7 \text { days }\end{array}$ & $\begin{array}{c}\text { Starter } \\
8-21 \text { days }\end{array}$ & $\begin{array}{c}\text { Grower } \\
22-35 \text { days }\end{array}$ & $\begin{array}{c}\text { Finisher } \\
36-42 \text { days }\end{array}$ \\
\hline Corn & 55.174 & 58.107 & 61.661 & 65.929 \\
\hline Corn starch & 1.000 & 1.000 & 0.500 & 0.500 \\
\hline Soybean meal & 37.365 & 34.600 & 30.870 & 26.940 \\
\hline Soybean oil & 1.974 & 2.272 & 3.197 & 3.110 \\
\hline Salt & 0.520 & 0.500 & 0.480 & 0.450 \\
\hline Vitamin suppl. ${ }^{1}$ & 0.100 & 0.100 & 0.100 & 0.050 \\
\hline Mineral suppl. ${ }^{2}$ & 0.050 & 0.050 & 0.050 & 0.050 \\
\hline Calcitic limestone & 0.910 & 0.880 & 0.830 & 0.790 \\
\hline Dicalcium phosphate & 1.950 & 1.809 & 1.670 & 1.520 \\
\hline DL-methionine & 0.240 & 0.175 & 0.175 & 0.170 \\
\hline L-lysine $\mathrm{HCl}$ & 0.375 & 0.210 & 0.230 & 0.275 \\
\hline L-threonine & 0.155 & 0.060 & 0.060 & 0.075 \\
\hline Choline chloride $^{3}$ & 0.060 & 0.060 & 0.050 & 0.040 \\
\hline Kaolin 4 & 0.125 & 0.175 & 0.125 & 0.100 \\
\hline Total & 100.00 & 100.00 & 100.00 & 100.00 \\
\hline \multicolumn{5}{|l|}{ Calculated values } \\
\hline Metab. energy (kcal/kg) & 2950 & 3000 & 3100 & 3150 \\
\hline Crude protein (\%) & 22.04 & 20.79 & 19.41 & 18.03 \\
\hline Calcium (\%) & 0.94 & 0.89 & 0.83 & 0.76 \\
\hline Avail. phosphorus (\%) & 0.47 & 0.44 & 0.41 & 0.38 \\
\hline Methionine (\%) & 0.57 & 0.49 & 0.48 & 0.45 \\
\hline Met+Cys (\%) & 0.91 & 0.82 & 0.79 & 0.75 \\
\hline Lysine (\%) & 1.46 & 1.26 & 1.18 & 1.12 \\
\hline Threonine (\%) & 0.99 & 0.86 & 0.81 & 0.76 \\
\hline Potassium (\%) & 0.84 & 0.80 & 0.74 & 0.68 \\
\hline Sodium (\%) & 0.22 & 0.22 & 0.21 & 0.20 \\
\hline Chlorine (\%) & 0.36 & 0.34 & 0.33 & 0.31 \\
\hline Linoleic acid (\%) & 2.32 & 2.52 & 3.06 & 3.06 \\
\hline
\end{tabular}

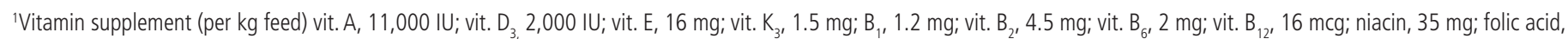
$0.4 \mathrm{mg}$; pantothenic acid, $10 \mathrm{mg}$; biotin, $60 \mu \mathrm{g}$; selenium, $250 \mu \mathrm{g}$. (pre-starter, starter, and grower phases); vit. $A_{1}, 5,500 \mathrm{IU} ;$ vit. D 1,000 IU; vit. E, $8 \mathrm{mg} ;$ vit. $K_{3}, 0.75 \mathrm{mg} ; B_{1}, 0.6 \mathrm{mg}$; vit. $B_{2}, 2.25$ mg; vit. $B_{6}, 1$ mg; vit. $B_{12}, 8 \mu$; niacin, 17.5 mg; folic acid, 0.2 mg; pantothenic acid, 5 mg; biotin, $30 \mu$; selenium, $125 \mu$ g. (finisher phase). ${ }^{2}$ Mineral supplement (per $\mathrm{kg}$ feed); iodine, $1.000 \mu \mathrm{g}$; iron, $30 \mathrm{mg}$; copper, $9 \mathrm{mg}$; manganese, $60 \mathrm{mg}$; zinc, $60 \mathrm{mg} .{ }^{3}$ Choline chloride (70). ${ }^{4}$ Inert material.

intake (difference between total feed offer and feed residues at the end of each period); feed conversion ratio (ratio between total feed offer and weight gain in the period corrected for weight of birds that died during the period), livability (percentage of live birds in each period), and production factor (average daily weight gain multiplied by livability and feed conversion ratio, and dividing the result by 100 ).

On day 42, 20 birds per treatment were randomly selected, submitted to fasting for eight hours, electrically stunned, and bled. Carcass yield was then calculated as the difference between live weight and the weight of the eviscerated carcass with no head, neck, or feet. Breast and leg (thighs and drumstick) yields were calculated relative to empty carcass weight.

Data were analyzed using the GLM procedure of the SPSS $®$ version 13.0 (2004) statistical package, and means were compared by the test of Tukey at $5 \%$ probability level.

\section{RESULTS}

Variance homogeneity was confirmed by the test of Levene. All data presented normal distribution according to the KS test.

There was no effect ( $p>0.05$ ) of treatment on broiler performance in the cumulative periods of 1 to 7,1 to 21 and 1 to 42 days of age (Table 2).

However, treatments influenced carcass yield and breast yield (Table 3). Broilers in the CD+Gln/ Glu treatment presented higher $(p<0.05)$ breast yield when compared with those in the CD and AGP/AC treatment, which were not different from each other, but similar breast yield compared with the remaining treatments. 
Table 2 - Average weight gain (WG), feed intake (FI), feed conversion ratio (FCR), livability (L), and production factor (PF) of broilers during the periods of 1-7, 1-21, and 1-42 days of age as a function of treatment.

\begin{tabular}{|c|c|c|c|c|c|c|c|}
\hline Parameters & $C D^{1}$ & $\begin{array}{c}C D+ \\
A G P / A C^{2}\end{array}$ & $\begin{array}{c}\mathrm{CD}+ \\
\mathrm{G} \ln / \mathrm{Glu} \mathrm{u}^{3}\end{array}$ & $\begin{array}{l}\mathrm{CD}+ \\
\mathrm{PAs}^{4}\end{array}$ & $\begin{array}{l}C D+G \ln / \\
\text { Glu+PAs }\end{array}$ & $C V(\%)$ & $p$-value \\
\hline \multicolumn{8}{|c|}{$1-7$ days of age } \\
\hline WG, g & 111.05 & 109.15 & 109.90 & 109.06 & 111.90 & 3.65 & 0.895 \\
\hline $\mathrm{Fl}, \mathrm{g}$ & 133.82 & 126.99 & 132.74 & 126.38 & 129.41 & 4.28 & 0.363 \\
\hline FCR & 1.208 & 1.173 & 1.205 & 1.163 & 1.160 & 2.68 & 0.208 \\
\hline $\mathrm{L}, \%$ & 100.00 & 98.00 & 100.00 & 97.00 & 99.00 & 2.22 & 0.341 \\
\hline \multicolumn{8}{|c|}{$1-21$ days of age } \\
\hline WG, g & 899.49 & 892.32 & 896.70 & 901.13 & 902.62 & 3.33 & 0.987 \\
\hline $\mathrm{Fl}, \mathrm{g}$ & 1249.07 & 1234.94 & 1249.07 & 1237.41 & 1238.95 & 2.92 & 0.850 \\
\hline FCR & 1.405 & 1.390 & 1.395 & 1.385 & 1.390 & 2.27 & 0.939 \\
\hline L, \% & 99.00 & 98.00 & 99.00 & 96.00 & 97.00 & 2.84 & 0.563 \\
\hline \multicolumn{8}{|c|}{$1-42$ days of age } \\
\hline WG, g & 2887.64 & 2875.58 & 2916.54 & 2906.53 & 2898.77 & 3.41 & 0.991 \\
\hline $\mathrm{Fl}, \mathrm{g}$ & 4920.67 & 4835.65 & 4937.24 & 4877.28 & 4856.67 & 3.31 & 0.983 \\
\hline FCR & 1.710 & 1.692 & 1.695 & 1.693 & 1.705 & 1.86 & 0.909 \\
\hline $\mathrm{L}, \%$ & 98.00 & 95.00 & 97.00 & 95.00 & 93.00 & 3.74 & 0.323 \\
\hline $\mathrm{PF}^{5}$ & 393.80 & 384.38 & 397.62 & 388.75 & 376.37 & 4.49 & 0.450 \\
\hline
\end{tabular}

${ }^{1} \mathrm{CD}=$ control diet with no antibiotic growth promoter (AGP) or anticoccidial (AC). ${ }^{2} \mathrm{CD}+\mathrm{AGP}$ addition (avilamycin) and $\mathrm{AC}$ (monensin) ${ }^{3} \mathrm{CD}$ with addition of glutamine and glutamic acid. ${ }^{4} \mathrm{CD}$ with addition of phytogenic additives. ${ }^{5}$ Production factor $=\left[(A D G \times \text { livability)/FCR }]^{*} 100\right.$. Means followed by the same letters in the same row are statistically different by the test of Tukey $(p<0.05)$.

\section{DISCUSSION}

The performance results obtained in the present study are consistent with those of other authors, who did not report any effect on performance during the periods of 1 to 7 days (Miguel et al., 2009), 1 to 21 days (Hernández et al., 2004; Toledo et al., 2007; Barreto et al., 2008) and 1 to 42 days (Fukayama et al., 2005; Toledo et al., 2007; Barreto et al., 2008) when supplementing broilers diets with phytotherapic products. However, working with 1- to 42-d-old broilers challenged with Eimeria tenella, Christaki et al. (2004) observed better performance when birds were fed a diet supplemented with a phytogenic additive (mixture of essential oils) compared than those fed a negativecontrol diet, but worse performance compared with broilers fed a diet containing an anticoccidial agent. On the other hand, Miguel et al. (2009) obtained better performance results in broilers between one and 42 days of age challenged with E. tenella, E. acervulina and E. maxima and fed the same PA as that utilized in the present study, when compared both with birds fed a negative-control diet and those fed antibiotic growth promoters (bacitracin and salinomycin). Fascina et al. (2012) also found better performance in nonchallenged broilers also fed the same PAs relative to the negative-control birds during the periods of 1-21 and 1-42 days of age.

Alves et al. (2008) reported that the supplementation of broiler diets only with glutamine or glutamine associated with glutamic acid improved live performance, and recommended supplementation levels of 1.5\% L-Gln and 3.0\% Gln/Glu. Sakamoto et al. (2010) also obtained better performance when broilers were fed a diet supplemented with 3\% Gln/Glu. In the pres-

Table 3 - Average carcass yield and parts yield of 42-d-old broilers as a function of treatment.

\begin{tabular}{|c|c|c|c|c|c|c|c|}
\hline $\begin{array}{l}\text { Parameters } \\
(\%)\end{array}$ & $C D^{1}$ & $\begin{array}{c}C D+ \\
A G P / A C^{2}\end{array}$ & $\mathrm{CD}+\mathrm{G} \ln / \mathrm{Glu} \mathrm{u}^{3}$ & $C D+P A s^{4}$ & $\mathrm{CD}+\mathrm{G} \ln / \mathrm{Glu}+\mathrm{PAs}$ & CV (\%) & p-value \\
\hline Carcass $^{5}$ & $73.35 b$ & 74.44ab & $74.66 a$ & 74.10ab & $74.73 a$ & 2.11 & 0.045 \\
\hline Wings $^{6}$ & 10.20 & 10.20 & 9.93 & 10.05 & 10.17 & 4.85 & 0.333 \\
\hline Breast $^{6}$ & $39.01 b$ & $38.95 b$ & $40.33 a$ & 39.34ab & $39.54 a b$ & 3.90 & 0.026 \\
\hline $\operatorname{Legs}^{6}$ & 29.00 & 29.01 & 28.38 & 28.94 & 28.53 & 3.76 & 0.292 \\
\hline Back $^{6}$ & 21.37 & 21.53 & 21.00 & 21.22 & 21.35 & 5.60 & 0.855 \\
\hline
\end{tabular}

${ }^{1} \mathrm{CD}=$ control diet with no antibiotic growth promoter (AGP) or anticoccidial (AC). ${ }^{2} \mathrm{CD}+$ addition of $\mathrm{AGP}$ (avilamycin) and $\mathrm{AC}$ (monensin). ${ }^{3} \mathrm{CD}$ with addition of glutamine and glutamic acid. ${ }^{4} \mathrm{CD}$ with addition of phytogenic additives. ${ }^{5}$ Percentage relative to live weight. ${ }^{6}$ Percentage relative to empty carcass.

Means followed by the same letters in the same row are statistically different by the test of Tukey $(p<0.05)$. 
ent study, although the supplemented Gln/Glu levels $(1.0 \%$ in the pre-starter and starter, and $0.5 \%$ in the grower and finisher diets) were lower than those recommended by Alves et al. (2008), the performance results obtained may be attributed to the lack of health challenge, as they were similar to those observed in broilers fed the control diet and the diet containing antibiotic growth promoter and anticoccidial agent.

The best carcass yield and breast yield results were obtained in broilers fed the diets with glutamine associated with glutamic acid. This may be explained by the fact that glutamine is part of the structure of proteins and peptides, and it is used for synthesis of other amino acids, purines, and pyrimidines, which are the bases of the nucleotides that make up the DNA and RNA molecules (Newsholme et al., 2003a and b), which determine protein synthesis. Glutamine, in addition of stimulating muscle protein synthesis, inhibits muscle protein breakdown (Maclennan et al., 1988), and therefore may function as a metabolic regulator, increasing protein synthesis and reducing protein catabolism when supplemented in the diet (Lobley et al., 2001). Studies have shown that there is a positive correlation between free glutamine concentration and protein synthesis rate in the skeletal muscle (Souba et al., 1990), suggesting that higher circulating glutamine levels would promote higher protein synthesis, which could explain the results of the present study.

As reported above, the main actions of PAs are their antimicrobial and anticoccidial activities, and enhancement of nutrient digestibility and broiler performance. The results obtained with PAs relative to carcass and parts yields in the present study are in agreement with other experiments (García et al., 2007; Sheuermann et al., 2009) that did not find any influence of the dietary addition of PAs on these parameters.

\section{CONCLUSIONS}

Under the conditions of the present experiment, the dietary supplementation with phytogenic additives and with glutamine associated with glutamic acid does not affect the performance, but improves carcass yield and breast yield of broilers.

\section{ACKNOWLEDGEMENTS}

The author thank Fundação de Apoio à Pesquisa do Estado de São Paulo (FAPESP) for the scholarship and the companies Ajinomoto Animal Nutrition, Phytosynthese La Phytothérapie Animale Titrée, and M.Cassab Tecnologia Animal for donating the products tested in the experiment.

\section{REFERENCES}

Alves PCC, Sakamoto, MI, Souza HRB, Kikuchl CG, Previero TC, Faria DE. Determinação do nível ótimo de inclusão de fontes de glutamina na fase inicial de frangos de corte: Desempenho de 1 a 42 dias [cd rom]. $16^{\circ}$ Simpósio Internacional de Iniciação científica da USP; 2008; Piracicaba, São Paulo. Brasil. Piracicaba: SIICUSP; 2008

Barreto MSR, Menten JFM, Racamicci AMA, Pereira PWZ, Rizzo PV. Plant extracts used as growth promoters in broilers. Braziliam Journal of Poultry Science 2008;10:109-115.

Bartell SM, Batal AB. The Effect of Supplemental Glutamine on Growth Performance, Development of the Gastrointestinal Tract, and Humoral Immune Response of Broilers. Poultry Science 2001;86:1940-1947.

Christaki E, Florou-Paneri P, Giannenas I, Papazahariadou M, Botsoglou $N A$, Spais $A B$. Effect of a mixture of herbal extracts on broiler chickens infected with Eimeria tenella. Animal Research 2004;53:137-144.

Demattê Filho LC, Mendes CMI. Viabilidade técnica e econômica na criação alternativa de frangos. Anais da Conferência APINCO de Ciência e Tecnologia Avícolas; 2001; Campinas, São Paulo. Brasil. Campinas: FACTA; 2001. p.255-266.

Fascina L, Sartori JR, Gonzales E, Carvalho FB, Polycarpo GV, Souza IMGP, et al. Phytogenic additives and organic acids in broiler chicken diets. Revista Brasileira de Zootecnia [online] 2012;41(10):2189-2197.

Fascina L, Sartori JR, Carvalho FB, Pereira LA, Carrijo AS, Araujo PC. Digestibilidade de nutrientes da dieta em frangos de corte alimentado scom aditivos fitogênicos e ácidos orgânicos na fase de crescimento [cd rom]. Anais da Conferência APINCO de Ciência e Tecnologia Avícolas; 2010; Santos, São Paulo. Brasil. Campina: FACTA; 2010.

Fukayama EH, Bertechini AG, Geraldo A, Kato RK, Murgas LDS. Extrato de orégano como aditivo em rações para frangos de corte. Revista Brasileira de Zootecnia 2005; 34(6):2316-2326.

García V, Catalá-Gregori P, Hernández F, Megías MD, Madrid J. Effect of formic acid and plant extracts on growth, nutrient digestibility, intestine mucosa morphology, and meat yield of broilers. Journal of Applied Poultry Research 2007;16:555-562.

Hernández F, Madrid J, García V, Orengo J, Megías MD. Influence of two plant extracts on broilers performance, digestibility, and digestive organ size. Poultry Science 2004; 83:169-174

Lobley GE, Hoskin SO, Mcneil CJ. Glutamine in animal science and production. Journal of Nutrition 2001;131:255S-2531S.

Lora AG, Albino LFT, Rostagno HS, Páez LE Gattás G, Messias RKG. Níveis de inclusão de AminoGut $®$ em rações para frangos de corte [cd rom]. Anais da Conferência APINCO de Ciência e Tecnologia Avícolas; 2006; Santos, São Paulo. Brasil. Campinas: FACTA; 2006.

Maiorka A, Silva AVF, Santin E, Borges AS, Boleli IC, Macari M. Influência da suplementação de glutamina sobre o desempenho e o desenvolvimento de vilos e criptas do intestino delgado de frangos. Arquivo Brasileiro de Medicina Veterinária e Zootecnia 2000;52(5):487-490.

Maclennan PA, Smith K, Weryk B Watt PW, Rennie MJ. Inhibition of protein breakdown by glutamine in perfused rat skeletal muscle. FEBS Letters 1988;237:133- 136

Mcreynolds J, Waneck C, Byrd J, Genovese K, Duke S, Nisbet D. Efficacy of multistrain direct-fed microbial and phytogenetic products in reducing necrotic enteritis in commercial broilers. Poultry Science 2009;88:20752080 .

Miguel F, Francis C, François R. Effet de I'utilisation de complexes d'extraits vegetaux chez le poulet en croissance, vaccine contre la coccidiose 
et challenge par une inoculation coccidienne a 14 jours. Huitièmes Journées de la Recherche Avicole; 2009; St Malo. France; 2009.

Murakami AE, Sakamoto MI, Natali MRM, Souza LMG, Franco JRG. Supplementation of glutamine and vitamin $E$ on the morphometry of the intestinal mucosa in broiler chickens. Poultry Science 2007;86:488495.

Newsholme P, Procopio J, Lima MMR, Pithon-Curi TC, Curi R. Glutamine and glutamate - their central role in cell metabolism and function. Cell Biochemistry and Function 2003a; 21:1-9.

Newsholme P, Lima MMR, Procopio J, Jpithon-Curi TC Doi SQ, Bazotte RB, Curi R. Glutamine and glutamate as vital metabolites. Brazilian Journal of Medical and Biological Research 2003b;36(2):153-163.

Newsholme P. Why is L-glutamine metabolism important to cells of the immune system in health, postinjury, surgery or infection? Journal of Nutrition 2001;5:2515S-2522S.

Newsholme EA, Crabtree B, Ardawi MS. The role of high rates of glycolysis and glutamine utilization in rapidly dividing cells. Bioscience Reports 1985;5(5):393-400.

Pierzynowski SG, Pirdra VJL, Hommel-Hansen T. Studzinski, T. et al. Glutamine in gut metabolism. In: Piva A, Knudsen KEB, Lindberg JE. Gut environment of pigs. Nottingham: University Press, 2001. p.43-62

Rostagno HS, Albino LFT, Donzele JL, Gomes PC, Oliveira RF, Lopes CD, et al. Tabelas brasileiras para aves e suínos: composição de alimentos e exigências nutricionais. Viçosa: UFV; 2005.

Sakamoto MI, Faria DE, Nakagl VS, Souza KMR, Araújo RB. Hosotani, G. Avaliação da glutamina e nucleotídeos sobre o desempenho de frangos de corte vacinados contra a coccidiose [cd rom]. $447^{\circ}$ Reunião Anual da Sociedade Brasileira de Zootecnia; 2010; Salvador, Bahia. Brasil. Salvador: UFBA, 2010

Sakamoto MI, Murakami AE, Natali RM, Fernandes JM, Souza LMG. Influência da glutamina e vitamina e sobre o desempenho e morfometria intestinal em frangos de corte [cd rom]. Congresso LatinoAmericano de Nutrição Animal; 2005; São Paulo, SP. Brasil. São Paulo: ALANA/CBNA; 2005.

Silva AVF, Oliveira JP, Sens RF, Sócrates MRB, Anjos AS, Borges SA. Inclusão de aditivos vegetais em dietas de frangos de corte. $47^{\circ}$ Reunião Anual da Sociedade Brasileira de Zootecnia; 2010; Salvador, Bahia. Brasil. Salvador: UFBA; 2010.

Souba WW, Herskowitz k, Salloum RM, Chen MK, Austen TR. Gut glutamine metabolism. Journal of Parenteral and Enteral Nutrition1990;14(4):45S$50 \mathrm{~s}$.

Sheuermann GN, Junior AC, Cyprino L, Gabbi AM. Phytogenic additive as an alternative to growth promoters in broiler chickens. Ciência Rural 2009;39:552-527.

SPSS 13.0 for Windows. Release 13.0 (1 Sep. 2004). Chicago: SPSS; 2004.

Toledo GSP, Costa PTC, Silva LP, Pinto D, Ferreira P, Poletto CJ. Desempenho de frangos de corte alimentados com dietas contendo antibiótico e/ ou fitoterápico como promotores, adicionados isoladamente ou associados. Ciência Rural 2007;37(6):1760-1764.

Windmueller HG, Spaeth A. E. Uptake and metabolism of plasma glutamine by the small intestine. Journal of Biology Chemistry 1974;249:50705079.

Wu G. Intestinal mucosal amino a cid catabolism. Journal of Nutrition 1998;128:1249-1252. 